\title{
Avian Glycan
}

National Cancer Institute

\section{Source}

National Cancer Institute. Avian Glycan. NCI Thesaurus. Code C118429.

An oligosaccharide protein modification that is synthesized by avian cells. 